\title{
The Signal Effect of New Energy Vehicles Promotion on Enterprise Innovation
}

\author{
Xinyu Wang $\mathbb{D}^{1}$ and Cailou Jiang $\mathbb{D}^{2,3}$ \\ ${ }^{1}$ School of Business, Nanjing University of Information Science and Technology, Nanjing 210044, China \\ ${ }^{2}$ Development Institute of Jiangbei New Area, Nanjing University of Information Science and Technology, Nanjing 210044, China \\ ${ }^{3}$ Research Institute for Environment and Health, Nanjing University of Information Science and Technology, \\ Nanjing 210044, China \\ Correspondence should be addressed to Cailou Jiang; jcl@nuist.edu.cn
}

Received 4 April 2021; Accepted 7 June 2021; Published 18 June 2021

Academic Editor: Bernardo A. Furtado

Copyright (C) 2021 Xinyu Wang and Cailou Jiang. This is an open access article distributed under the Creative Commons Attribution License, which permits unrestricted use, distribution, and reproduction in any medium, provided the original work is properly cited.

\begin{abstract}
Entering the promotion catalogue is the basis for China's new energy vehicle (NEV) enterprises to obtain promotion subsidies. Using a multistage difference-in-differences (DID) model with a sample of listed NEV enterprises in China from 2008 to 2017, this paper empirically analyzes the impact of entering the promotion catalogue on the innovation of NEV enterprises. The results indicate that entering the promotion catalogue can significantly promote innovation of NEV enterprises from the perspective of radical innovation, incremental innovation, and external technology introduction of NEV enterprises. In the mediation mechanism examination, this study finds that entering the promotion catalogue promotes innovation in NEV enterprises by increasing corporate profits and easing financing constraints. Based on the conclusions above, this paper recommends to strengthen core technology breakthrough of NEVs, cultivate market demand of NEVs industry, and improve subsidy supervision system of NEVs.
\end{abstract}

\section{Introduction}

In the context of global climate change, the conflict between energy consumption and the ecological environment is arising. The development of new energy vehicles (NEVs) has become the strategic choice of coupling economic, social, and ecological objectives. Government investment in NEVs is of great significance for cultivating emerging industries, gaining future industrial competitiveness as well as alleviating environmental and ecological problems. As a key strategic emerging industry in China, the NEV industry is facing problems such as technology shortage and immature market development at the initial stage of development. Technological innovation is the main source of competitive advantage for the long-term survival of organizations [1]. However, the technological innovation of NEVs has the "dual externalities" of knowledge spillover and environmental improvement, which is difficult to be compensated in the market price of the product. This can easily cause the private income of enterprise innovation investment to be less than the social income, leading to insufficient willingness to invest in innovation. As a result, it is difficult to guarantee the technological innovation of enterprises, which is not conducive to their long-term development $[2,3]$. In order to compensate for the "dual externalities" of enterprise innovation, it is necessary to provide government subsidies to NEV enterprises.

Government subsidies beforehand and government subsidies afterwards are two essential components of government subsidies. Government subsidies beforehand are usually provided in the budding period of the innovative activities. They can not only help reduce the innovation costs but also correct market failures in technological innovation. Thus, government subsidies beforehand can enhance the willingness of enterprises to invest in innovation [4]. However, in the absence of scientific evaluation and 
monitoring, such subsidies may increase firms' dependence on the government and reduce innovation efficiency. Government subsidies afterwards, which usually take place after a firm innovation has met a specific standard, can avoid firms' dependence on government subsidies and facilitate firms' entry into a virtuous cycle of technological innovation [5]. Since 2009, China has been promoting NEVs to accelerate the proliferation of NEVs, linking the supply and market demand at both ends. In order to facilitate the implementation of the promotion policy, China's Ministry of Industry and Information Technology (MIIT) has formulated a NEV promotion catalogue based on certain performance and technical standards, and the models entering the promotion directory can receive corresponding promotion subsidies. With the development of the NEV industry, China continuously adjusts and optimizes the entry criteria and conditions of the NEV promotion catalogue, including vehicle usage, power, battery type, energy density, and mileage. In the "Catalogue of Recommended Vehicles for the Promotion and Application of New Energy Vehicles" in 2017, the number of catalogue models for special purpose motor vehicles and passenger cars increased by 291 and 81, respectively, compared with 2016, and the number of catalogue models for passenger cars decreased by 32 , which puts forward higher requirements on the power, economy, safety, comfort, and other indicators of the selected models.

Driven by the promotion policy, China's NEV production and sales scale has achieved tremendous growth, ranking first in the world since 2015. However, China's NEV industry has been plagued by the problem of focusing on scale rather than technology. The promotion policy is a kind of government subsidies afterwards policy. Moreover, entering the NEV promotion catalogue is the basis for obtaining promotion subsidies. In China, few scholars have paid attention to the panel data of NEV enterprise under the policy of government subsidies, especially under government subsidies afterwards. Therefore, our study tries to fill this gap by taking China's NEV listed enterprises in the period of 2008-2017 as samples to investigate whether entering the NEV promotion catalogue can promote enterprise innovation, which provides a new perspective for the analysis and evaluation of NEV promotion policy and a new reference for the promotion of NEV technology progress.

The remainder of this paper is structured as follows: Section 2 summarizes the relevant literature and presents the research hypothesis. The data sources, the measurement of the variables, and the research methodology are discussed in Section 3. Section 4 provides the main empirical results. The conclusions and policy implications are provided in Section 5 .

\section{Literature Review and Research Hypothesis}

As the essential part of the economic infrastructure, technical standards can drive technological innovation and economic growth $[6,7]$. Among them, technical standards play a decisive role in determining the pace and direction of technological innovation and can systematize unstructured technological innovative activities [8]. Technical standards can provide information for the knowledge stock and functional requirements of small and medium enterprises (SMEs). It can not only guide SMEs' investment and management of innovation elements such as technology, equipment, capital, information, and employees but also guide the development of various stages of technological innovation such as conception, design, research and development (R\&D), manufacturing, and marketing. For example, enterprises prefer to allow employees to have a high level of job flexibility because they are more creative and innovative in this condition [9]. Therefore, technical standards can directly affect the process and effects of SMEs' technological innovation [10]. The process of standardization of technologies involves the interaction of many organizations such as the market, government, and business alliances [11]. In the process of standardization of different technologies, the involvement of the above organizations and the degree of their role vary. In general, nonproduct standards related to quality, reliability, safety, health, and environmental content are best suited for government-led development [12]. The government promotion catalogue for NEVs has a certain technical threshold, which provides a direct target for NEV innovation. Only if NEV enterprises meet this target, they can be eligible to enter the promotion catalogue. The technical standards in the promotion catalogue can guide SMEs to choose suitable technologies for their own R\&D and introduce corresponding copyrights and patents. In sum, technical standards can encourage new technologies to replace old ones and provide a higher technical platform for the innovative activities of NEV enterprises. Based on the above analysis, this paper proposes hypothesis 1 :

$\mathrm{H} 1$ : entering the promotion catalogue can promote innovation in NEV enterprises

In a market economy, the fundamental goal of an enterprise's activities is to obtain its profit, which can be achieved by satisfying the market demand. The "demandpull" theory asserts that demand leads to technological innovation, and that changes in the scale and direction of demand effectively promote enterprises' technological innovation [13]. Market demand reflects consumers' requirements for products. This requirement is a very important driving force for the use of new technologies [14]. Therefore, market demand can prompt enterprises to produce products that match it through technological innovation [15]. Among them, the expansion of the market demand scale helps enterprises to make full use of the larger market demand space, expand production scale, and achieve economies of scale [16]. It can not only share innovation costs and reduce innovation risks but also provide a reliable guarantee for the benefits obtained from successful innovation [17]. At the same time, the expansion of market demand increases the incentive to innovate by influencing the market structure and the "survival of the fittest" market competition mechanism [18]. Entering the NEV promotion catalogue means that enterprises can get corresponding 
subsidies, thus directly increasing their income. At the same time, it sends a brand signal effect to the sales market of NEVs and expands the market. Therefore, the expansion of NEV companies into a wider market can help increase corporate profits, thus promoting corporate innovation. According to the above analysis, our study proposes hypothesis 2:

$\mathrm{H} 2$ : entering the promotion catalogue can promote innovation of NEV enterprises by increasing their profits

Lerner first proposed the idea that $\mathrm{R} \& \mathrm{D}$ subsidies have a signal effect based on empirical results from American SMEs that entered the Small Business Innovation Research (SBIR) program from 1983 to 1997 [19]. Taking samples of enterprises from their respective countries, scholars have a consistent attitude: $\mathrm{R} \& \mathrm{D}$ subsidies provide a positive signal for the quality and technological advantages of enterprise projects. This signal effect can increase the possibility of enterprises for external financing by compensating for the defects of information asymmetry in the capital market $[20,21]$. External financing is an important source of corporate innovation [22]. However, enterprise innovation presents the characteristics of high investment, high risk, and information asymmetry. Therefore, it is often difficult for companies to obtain the necessary financial support for innovative activities [23]. Entering the promotion catalogue means that the company's brand is recognized by the state and society, and NEV companies will be expected to develop better. Since it is a listed company, this behavior will send positive signals to investors about the quality of the company, which will help to finance the company and thus provide reliable financial support for innovation. In summary, this paper proposes the following hypothesis:

H3: entering the promotion catalogue can promote innovation in NEV enterprises by reducing financing constraints

We contribute to literature in these aspects. First, our study divides government subsidies into government subsidies beforehand and government subsidies afterwards, and focuses on the impact of government subsidies afterwards on the innovation of NEV enterprises. Second, NEV enterprises with vehicle production business are selected as overall samples and exclude the heterogeneity of the research samples. Third, a multistage DID method is used in this study to alleviate endogenous problems.

\section{Data and Methodology}

3.1. Sample and Data. This study selected A-shares listed NEV enterprises from 2008 to 2017 as research samples. In order to ensure the scientific validity of the study, we selected NEV enterprises with high industry representation and sound financial disclosure and obtained the data of 334 effective observation samples. The patent data were manually searched through the patent database of the China National Intellectual Property Administration. The data of promotion subsidy were obtained from the "Catalogue of
Recommended Vehicles for the Promotion and Application of New Energy Vehicles" of the MIIT of the People's Republic of China. The other data were obtained from China Stock Market Accounting Research Database (CSMAR) and Wind Economic Database (WIND), and missing data were manually supplemented in the annual reports of the companies in Cninfo.

\subsection{Definition of Variables}

3.2.1. Dependent Variables. Innovation in NEV enterprises can be divided into internal independent R\&D and external technology introduction. This study uses the number of different types of patents to measure internal independent R\&D. China's patents are divided into three types: patents for invention, patents for utility model, and patents for industrial design. Among them, patents for invention have the highest degree of innovation and are used to measure the radical innovation $(R a d)$ of an enterprise. Patents for utility model and industrial design have a relatively low degree of innovation and are used to measure the incremental innovation $(I n c)$ of an enterprise. Due to the time lag in patent grants, the number of invention patent applications is used here to measure the internal independent R\&D of the enterprise. For the external technology introduction $(E x t)$ of NEVs, this study refers to the study of Xu et al. [24] and measures it by the increment of intangible assets and goodwill of the enterprise because intangible assets and goodwill can reflect the technology purchased by the enterprise and can bring excess economic benefits to the enterprise [25].

3.2.2. Independent Variables. Promotion subsidies may expand the market demand for NEVs and stimulate innovation efforts by increasing corporate profits and easing financing constraints. If the vehicle models in the catalogue recommended by the MIIT are qualified, NEV enterprises can enter the promotion catalogue and receive government subsidies. The promotion subsidy (Treat * Post), which is the focus of this study, is measured by an interaction term of two dummy variables. The coefficients of Treat $*$ Post indicate the changes in the innovation performance of the experimental group of NEV enterprises under the policy effect [26].

3.2.3. Intermediate Variables. The subsidies obtained as cash flow after the NEVs enter the "Catalogue of Recommended Vehicles for the Promotion and Application of New Energy Vehicles" may motivate the dual innovation and external technology introduction of NEV enterprises. These results may be achieved through two paths formed by corporate profit and financing constraints. Corporate profit (Profit) is an important indicator of profitability, which may provide favorable material conditions for the innovative behavior of NEV enterprises [27]. This study expresses corporate profit in terms of net profit. Financing constraint (Fin) is the response of corporate financing cost, measured by the ratio 
of interest expenses to current liabilities [28]. Higher financing constraint implies higher financing cost, which may inhibit the internal independent R\&D and external technology introduction of NEVs.

3.2.4. Control Variables. Control variables are used to control the impact of the NEV enterprises' own characteristics on their innovation. With reference to existing literature, this study controls the following five variables: (1) enterprise age $(A g e)$ : the age of the enterprise is related to managerial efficiency and may affect the enterprise's ability to innovate $[29,30]$. (2) Enterprise scale (Size): large enterprises can withstand stronger innovation risks and reduce innovation costs through scale effects [31]. (3) Debt to asset ratio (Lev): this variable reflects the ability of NEV enterprises to use creditors' funds to carry out business activities. A higher level of debt will increase the financial risk of the enterprise, which has an impact on innovation [32]. (4) Government subsidies $(S u b)$ : this variable represents the number of subsidies received by NEV enterprises from the government. Higher subsidies can promote the innovation of NEV enterprises [33]. (5) State ownership (Sta): in the Chinese stock market, the government directly controls the state-owned shares. The larger the share of state-owned shares in the total share capital, the more likely it is to benefit to the innovation of NEV enterprises [34,35].

The definitions of the main variables in this paper are shown in Table 1.

\subsection{Research Models}

3.3.1. Multistage Difference-in-Differences Model. In our study, a quasinatural experiment is conducted to estimate the effect of the NEV promotion subsidy policy on enterprise innovation. We take the NEV enterprises that have entered the promotion catalogue as an experimental group and the NEV enterprises that have not entered the catalogue as a control group. Compared to the traditional regression method, the DID method can alleviate the endogeneity problem in a differential manner. For this purpose, this study uses the DID method to observe the effect of the policy. In addition, the Chinese government's promotion of subsidy policies for NEVs is gradually promoted, while the traditional DID method can only test the policy performance implemented at a single point. Therefore, in order to investigate the impact of the promotion of subsidy policies on the innovation of NEV enterprises, this study constructs the following multistage DID model:

$$
Y_{i, t}=C+\alpha \text { Treat }_{i} \text { Post }_{i, t}+\beta_{1} X_{i, t}+\mu_{i}+\lambda_{t}+\varepsilon_{i, t},
$$

where $Y$ is denoted by radical innovation (Rad), incremental innovation (Inc), and external technology introduction $(E x t)$, respectively. Treat $_{i}$ is the dummy variable of the experimental group. The experimental group of enterprises is not fixed due to the different times of entry into the NEV promotion catalogue. Enterprises which have entered the NEV promotion catalogue will be included in to the experimental group, and control group otherwise. Post ${ }_{i, t}$ denotes the time dummy variable, that is, Post $_{i, t}=\left\{\begin{array}{l}1, t \geq t_{0} \\ 0, t<t_{0}\end{array}\right.$, where $t_{0}$ stands for the year of entering the promotion catalogue of NEVs. $\alpha$, the coefficient of Treat $_{i}$ Post $_{i, t}$, is the DID estimator illustrating the policy effect on innovation of NEV enterprises, which is one of the highlights of this paper. If $\alpha$ is positively significant, then entering the promotion catalogue exert positive effects on the innovation of NEV enterprises; if $\alpha$ is negative and significant, then this government's promotion subsidy policy restrains the innovation of NEV enterprises; if $\alpha$ is nonsignificant, then entering the promotion catalogue of NEVs does not exert a significant effect on the innovation of their enterprises. $\mu_{i}$ and $\lambda_{t}$, respectively, represents individual fixed effects and time fixed effects. $X_{i, t}$ is denoted by the control variables. $\varepsilon_{i, t}$ is the random perturbation error term.

3.3.2. Mediation Effect Model. In order to test whether the effects of the promotion subsidy policy on dual innovation and external technology importation by enterprises are realized through the paths described above, based on equation (1), this paper refers to Edwards and Lambert and constructs a mediation effect model for further testing [36]:

$$
\begin{aligned}
M_{i, t} & =C+\beta \text { Treat }_{i} \text { Post }_{i, t}+\beta_{2} X_{i, t}+\mu_{i}+\lambda_{t}+\varepsilon_{i, t} \\
Y_{i, t} & =C+\alpha^{\prime} \text { Treat }_{i} \text { Post }_{i, t}+\delta M_{i, t}+\beta_{3} X_{i, t}+\mu_{i}+\lambda_{t}+\varepsilon_{i, t}
\end{aligned}
$$

where $M$ represents the intermediate variables, including the corporate profit (Profit) and financing constraint (Fin). The testing principle is as follows: the effects of the independent variable on the dependent variable and the independent variable on the intermediate variable are verified by equations (1) and (2), respectively. If both $\alpha$ and $\beta$ are statistically significant, the intermediary variable is included in equation (1), and both the independent and intermediary variables are regressed on the dependent variable. That is, regression tests are performed on equation (3). In addition, if both coefficients $\beta$ and $\delta$ are statistically significant, it refers to the existence of mediation effect. Furthermore, if the coefficient $\delta$ is statistically significant but the coefficient $\alpha^{\prime}$ is statistically insignificant, it means that the intermediate variable demonstrates a perfect mediation effect, implying that only this mediating variable plays a role in the mechanism. Moreover, if both the coefficient $\delta$ and $\alpha^{\prime}$ are statistically significant but the coefficient $\alpha^{\prime}$ is less than the coefficient $\alpha$, it means that the intermediate variable demonstrates a partial mediation effect, implying that there are other reasonable mechanisms of action. However, if either $\beta$ or $\delta$ is not statistically significant, then a Sobel test or a Bootstrap method is needed to determine whether the mediating variable has a mediation effect.

\section{Results}

4.1. Descriptive Statistics. The mean, standard deviation, minimum and maximum values of the variables for the 334 samples are shown in Table 2. 
TABLE 1: Definition of variables.

\begin{tabular}{|c|c|c|}
\hline Type of variables & Variable & Definition \\
\hline \multirow{3}{*}{ Dependent variables } & Radical innovation (Rad) & The number of patent applications for inventions per year $(10,000)$ \\
\hline & Incremental innovation $(I n c)$ & The number of annual utility model and design applications $(10,000)$ \\
\hline & $\begin{array}{l}\text { External technology introduction } \\
\qquad(E x t)\end{array}$ & The increase in intangible assets and goodwill $(100,000,000)$ \\
\hline $\begin{array}{l}\text { Independent } \\
\text { variables }\end{array}$ & Promotion of subsidies (Treat $*$ Post) & $\begin{array}{l}\text { Equal to } 1 \text { if NEV enterprises enter the promotion catalogue and } 0 \\
\text { otherwise }\end{array}$ \\
\hline \multirow{2}{*}{$\begin{array}{l}\text { Intermediate } \\
\text { variables }\end{array}$} & Corporate profits (Profit) & Net profit $(100,000,000)$ \\
\hline & Financing constraints (Fin) & Interest expenses/current liabilities \\
\hline \multirow{5}{*}{ Control variables } & Enterprise age $(\mathrm{Age})$ & Ln (year of observation-year of establishment) \\
\hline & Enterprise scale (Size) & Ln (total assets) \\
\hline & Debt to asset ratio $(L e v)$ & Ln (total liabilities/total assets $* 100)$ \\
\hline & Government subsidy (Sub) & Ln (government subsidy/operating income $* 100$ ) \\
\hline & State ownership (Sta) & Ln (number of shares held by the state/total share capital $* 100$ ) \\
\hline
\end{tabular}

TABle 2: Descriptive statistics of the variables.

\begin{tabular}{|c|c|c|c|c|c|}
\hline Variable & Obs & Mean & Std. dev. & Min & Max \\
\hline Treat $*$ Post & 334 & 0.55689 & 0.497499 & 0 & 1 \\
\hline Profit & 334 & 3.05994 & 9.82459 & -3.035234 & 72.51881 \\
\hline Fin & 334 & 0.022331 & 0.021615 & 0 & 0.141911 \\
\hline Rad & 334 & 0.008883 & 0.021269 & 0 & 0.1886 \\
\hline $\operatorname{Inc}$ & 334 & 0.011962 & 0.027535 & 0 & 0.2446 \\
\hline Ext & 334 & 0.544392 & 1.498973 & -5.884992 & 17.52637 \\
\hline Age & 334 & 2.763407 & 0.365151 & 1.609438 & 4.060443 \\
\hline Size & 334 & 16.99343 & 4.37686 & 9.891342 & 24.77929 \\
\hline Sub & 334 & -0.618773 & 1.617142 & -14.69064 & 3.024192 \\
\hline Lev & 334 & 3.975222 & 0.393875 & 1.967371 & 4.574195 \\
\hline Sta & 334 & 0.694190 & 1.540632 & -5.124496 & 4.09601 \\
\hline
\end{tabular}

4.2. Multistage Difference-in-Differences Estimation. This paper uses a DID model to estimate the impact of promotion subsidies on internal independent $R \& D$ and external technology introduction in NEV enterprises. The unbiased result of the multistage DID estimation requires the assumption of parallel trend to be established. That is, internal independent $\mathrm{R} \& \mathrm{D}$ and external technology introduction in the treatment and control groups should have a consistent trend of change before the implementation of the promotion subsidy policy. Otherwise, the multistage DID cannot accurately estimate the effects of the policy implementation. It is therefore necessary to perform a parallel trend test for equation (1).

Figures 1-3 provide the parallel trends of radical innovation, incremental innovation, and external technology introduction respectively. The results show that, before the implementation of the promotion subsidy policy, whether new energy vehicle companies enter the promotion catalogue has no significant difference in their innovation behavior, which is in line with the hypothesis of parallel trend. Furthermore, after the implementation of the policy of promotion subsidies, the level of internal independent $R \& D$ and the introduction of external technology have increased in the enterprises that have entered the NEV promotion catalogue. The results indicate that the multistage DID approach is applicable to the evaluation of subsidy policies for the promotion of NEVs.
Table 3 shows the estimated results of the multistage DID. In models 1-4, the regression coefficient of "Treat $*$ Post" is significantly positive at the level of $p<1 \%$. Furthermore, the regression coefficient of "Treat $*$ Post" is positive and significant at the level of $p<5 \%$ in model 5 . This result indicates that the policy of promotion subsidies greatly stimulate both internal independent $R \& D$ and external technology introduction in NEV enterprises. This result is consistent with the existing literature. For instance, in Canada, Mohnen found the effectiveness of government R\&D subsidies by comparing the innovation performance between enterprises that received only $R \& D$ tax credits and enterprises that received both $R \& D$ tax credits and $R \& D$ subsidies [37]. Bronzini and Piselli empirically tested that a R\&D subsidy programme implemented in northern Italy had a positive influence on the innovative activities of beneficiary firms [38]. Kang and Park have found in the Korean biotechnology sector that government project funding can stimulate internal $\mathrm{R} \& \mathrm{D}$ and thus positively promote innovation in enterprises [39].

4.3. The Mediation Effects of Corporate Profits Test. First, we choose corporate profits as the intermediate variable to investigate whether government subsidies affect innovation in NEV enterprises by increasing corporate profits. The results in Table 4 show that the estimated coefficient of the 


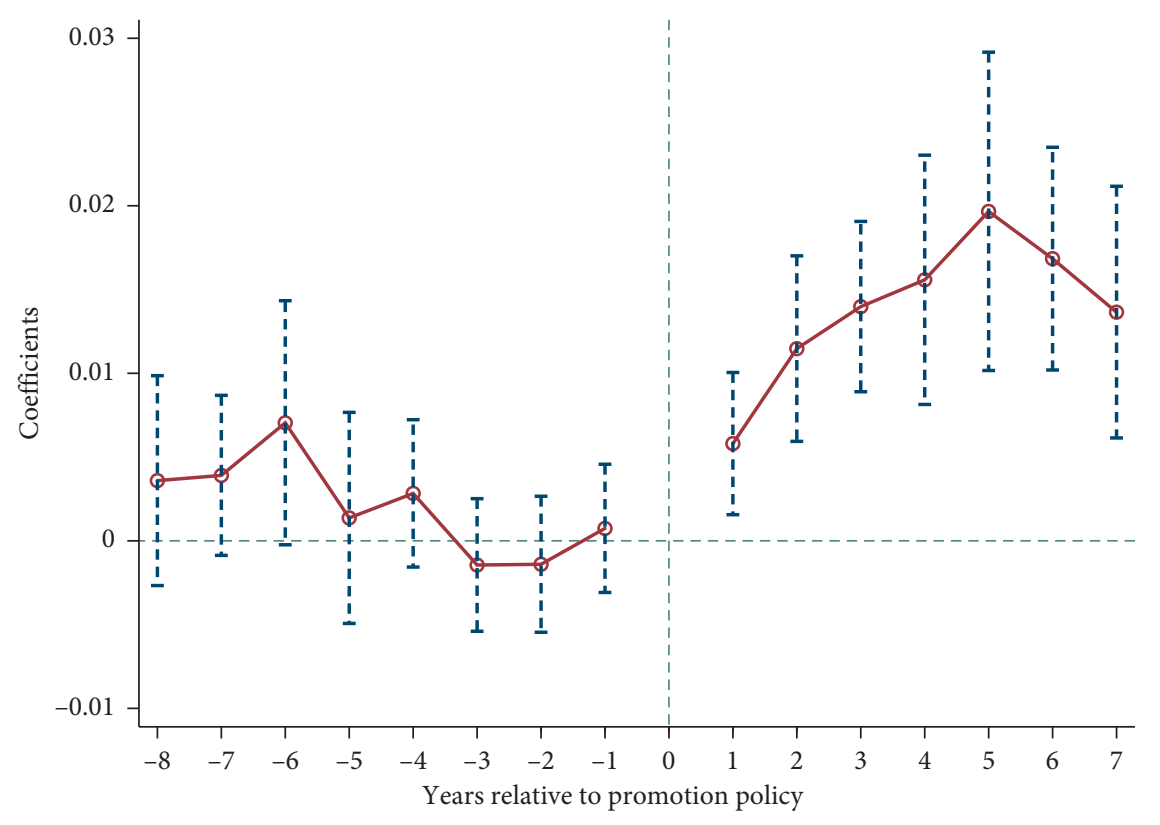

FIgURE 1: Parallel trend test for radical innovation.

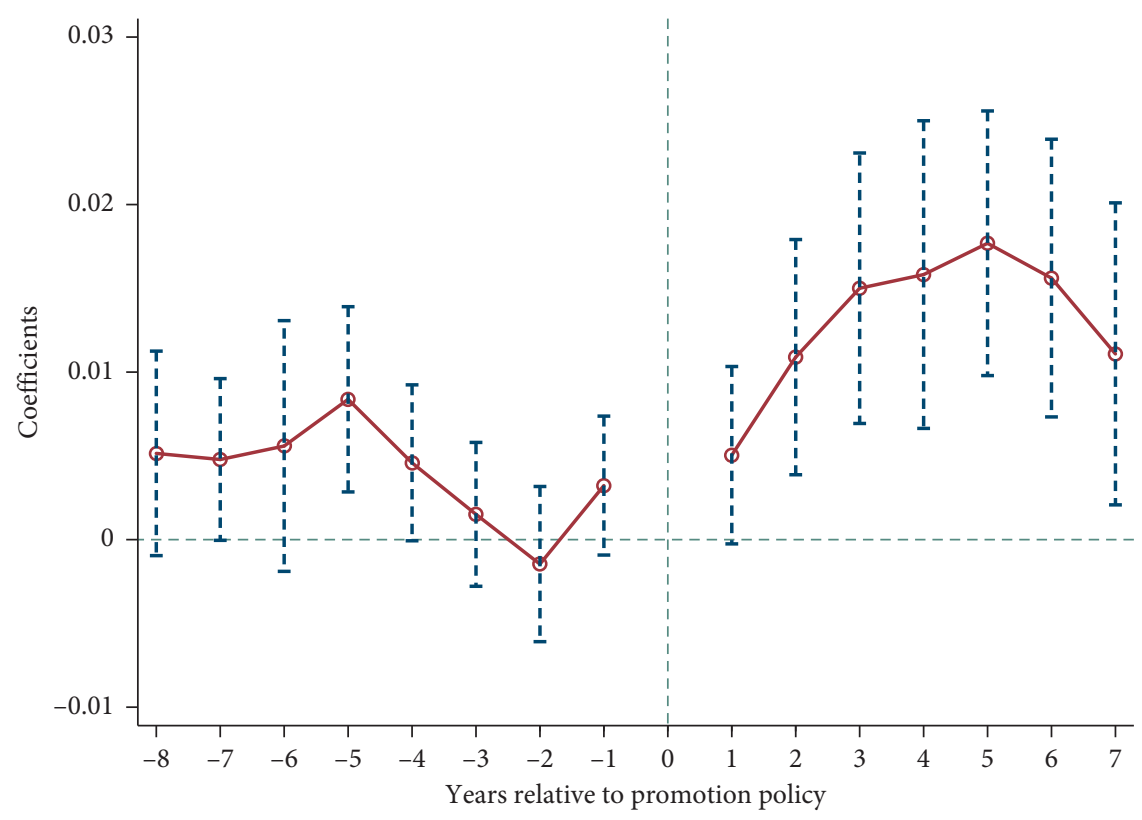

Figure 2: Parallel trend test for incremental innovation.

promotion subsidy in model 7 is significantly positive at the level of $p<1 \%$, indicating that the promotion subsidy significantly increases the profits of NEV enterprises. Based on model 7 , the intermediate variable of enterprise profit is added. The results represent that the internal independent $\mathrm{R} \& \mathrm{D}$ of the enterprise in models 9 and 11 is significantly positive at the level of $p<1 \%$, and the external technology introduction of the enterprise in model 13 is significantly positive at the level of $p<10 \%$. The regression coefficients of promotion subsidies on enterprise innovation remain significantly positive after controlling for enterprise profits.
These results prove that promotion subsidies can further promote enterprise innovation by increasing enterprise profits, and there is a partial mediation effect of enterprise profits in the relationship between promotion subsidies and enterprise innovation. Hence, hypothesis 2 is verified. After entering the promotion catalogue, government subsidies are effective in increasing enterprises' profitability [40, 41]. Therefore, the direct subsidies and indirectly enhanced profits from NEVs provide cash flow for innovative activities that require large amounts of capital. In addition, because profitable enterprises have a greater incentive to innovate 


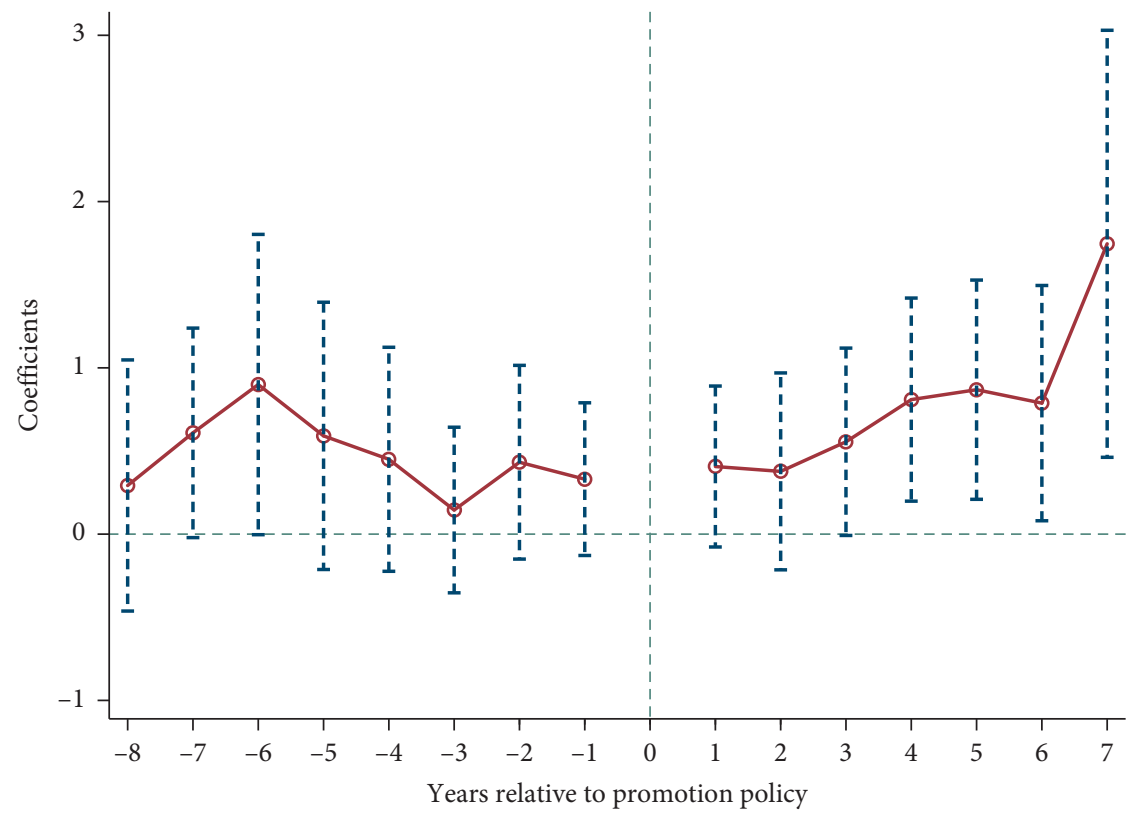

FIgURe 3: Parallel trend test for external technology introduction.

TABLE 3: The test of the effect of promotion subsidy policy.

\begin{tabular}{|c|c|c|c|c|c|c|}
\hline \multirow{2}{*}{ Variables } & \multicolumn{2}{|c|}{ Rad } & \multicolumn{2}{|c|}{$\operatorname{Inc}$} & \multicolumn{2}{|c|}{ Ext } \\
\hline & Model 1 & Model 2 & Model 3 & Model 4 & Model 5 & Model 6 \\
\hline Treat ${ }^{*}$ Post & $\begin{array}{c}0.010519^{* * *} \\
(4.63)\end{array}$ & $\begin{array}{c}0.011056^{* * *} \\
(4.49)\end{array}$ & $\begin{array}{c}0.012537^{* * *} \\
(4.24)\end{array}$ & $\begin{array}{c}0.012348^{* * *} \\
(3.88)\end{array}$ & $\begin{array}{c}0.372542^{* *} \\
(2.27)\end{array}$ & $\begin{array}{c}0.483211^{* * *} \\
(2.68)\end{array}$ \\
\hline Age & & $\begin{array}{c}0.003807 \\
(1.19)\end{array}$ & & $\begin{array}{c}0.001348 \\
(0.33)\end{array}$ & & $\begin{array}{c}-0.356128 \\
(-1.51)\end{array}$ \\
\hline Size & & $\begin{array}{c}0.000187 \\
(0.68)\end{array}$ & & $\begin{array}{c}-0.000172 \\
(-0.49)\end{array}$ & & $\begin{array}{c}0.033943^{*} \\
(1.69)\end{array}$ \\
\hline Sub & & $\begin{array}{c}0.001136 \\
(1.64)\end{array}$ & & $\begin{array}{c}0.000921 \\
(1.03)\end{array}$ & & $\begin{array}{c}-0.002802 \\
(-0.06)\end{array}$ \\
\hline Lev & & $\begin{array}{c}0.000311 \\
(0.10)\end{array}$ & & $\begin{array}{c}0.002428 \\
(0.59)\end{array}$ & & $\begin{array}{c}0.105016 \\
(0.45)\end{array}$ \\
\hline Sta & & $\begin{array}{c}0.002611^{* * *} \\
\quad(3.50)\end{array}$ & & $\begin{array}{c}0.004092^{* * *} \\
(4.25)\end{array}$ & & $\begin{array}{c}0.005842 \\
(0.11)\end{array}$ \\
\hline $\mathrm{N}$ & 334 & 334 & 334 & 334 & 334 & 334 \\
\hline R-squared & 0.0605 & 0.1048 & 0.0513 & 0.1098 & 0.0153 & 0.0313 \\
\hline
\end{tabular}

Note: ${ }^{*},{ }^{* *}$, and ${ }^{* * *}$ represent significance at $10 \%, 5 \%$, and $1 \%$ level, respectively.

TABLE 4: The mediation effects test of corporate profits.

\begin{tabular}{|c|c|c|c|c|c|c|c|}
\hline \multirow{2}{*}{ Variables } & \multirow{2}{*}{$\begin{array}{c}\text { Profit } \\
\text { Model } 7\end{array}$} & \multicolumn{2}{|c|}{ Rad } & \multicolumn{2}{|c|}{$\operatorname{Inc}$} & \multicolumn{2}{|c|}{ Ext } \\
\hline & & Model 8 & Model 9 & Model 10 & Model 11 & Model 12 & Model 13 \\
\hline Treat ${ }^{*}$ Post & $\begin{array}{c}3.211800^{* * *} \\
(2.72)\end{array}$ & $\begin{array}{c}0.011056^{* * *} \\
(4.49)\end{array}$ & $\begin{array}{c}0.009565^{* * *} \\
(3.93)\end{array}$ & $\begin{array}{c}0.012348^{* * *} \\
(3.88)\end{array}$ & $\begin{array}{c}0.011338^{* * *} \\
(3.55)\end{array}$ & $\begin{array}{c}0.483211^{* * * *} \\
(2.68)\end{array}$ & $\begin{array}{c}0.318741^{*} \\
(1.85)\end{array}$ \\
\hline Profit & & & $\begin{array}{c}0.000464^{* * *} \\
(4.13)\end{array}$ & & $\begin{array}{c}0.000314^{* *} \\
(2.13)\end{array}$ & & $\begin{array}{c}0.051208^{* * *} \\
\quad(6.43)\end{array}$ \\
\hline Age & $\begin{array}{c}-1.131982 \\
(-0.73)\end{array}$ & $\begin{array}{c}0.003807 \\
(1.19)\end{array}$ & $\begin{array}{c}0.004333 \\
(1.38)\end{array}$ & $\begin{array}{c}0.001348 \\
(0.33)\end{array}$ & $\begin{array}{c}0.001704 \\
(0.41)\end{array}$ & $\begin{array}{c}-0.356128 \\
(-1.51)\end{array}$ & $\begin{array}{c}-0.298161 \\
(-1.34)\end{array}$ \\
\hline Size & $\begin{array}{c}0.150109 \\
(1.14)\end{array}$ & $\begin{array}{c}0.000187 \\
(0.68)\end{array}$ & $\begin{array}{c}0.000118 \\
(0.44)\end{array}$ & $\begin{array}{c}-0.000172 \\
(-0.49)\end{array}$ & $\begin{array}{c}-0.000219 \\
(-0.62)\end{array}$ & $\begin{array}{c}0.033943 \\
(1.69)\end{array}$ & $\begin{array}{c}0.026256 \\
(1.38)\end{array}$ \\
\hline Sub & $\begin{array}{c}-0.340113 \\
(-1.02)\end{array}$ & $\begin{array}{c}0.001136 \\
(1.64)\end{array}$ & $\begin{array}{c}0.001294^{*} \\
(1.91)\end{array}$ & $\begin{array}{c}0.000921 \\
(1.03)\end{array}$ & $\begin{array}{c}0.001028 \\
(1.16)\end{array}$ & $\begin{array}{c}-0.002802 \\
(-0.06)\end{array}$ & $\begin{array}{c}0.014615 \\
(0.31)\end{array}$ \\
\hline Lev & $\begin{array}{c}0.583723 \\
(0.38)\end{array}$ & $\begin{array}{c}0.000311 \\
(0.10)\end{array}$ & $\begin{array}{c}0.000040 \\
(0.01)\end{array}$ & $\begin{array}{c}0.002428 \\
(0.59)\end{array}$ & $\begin{array}{c}0.002244 \\
(0.55)\end{array}$ & $\begin{array}{c}0.105016 \\
(0.45)\end{array}$ & $\begin{array}{c}0.075176 \\
(0.34)\end{array}$ \\
\hline
\end{tabular}


TABLE 4: Continued.

\begin{tabular}{lccccccc}
\hline \multirow{2}{*}{ Variables } & Profit & \multicolumn{2}{c}{ Rad } & \multicolumn{2}{c}{ Inc } & Ext \\
& Model 7 & Model 8 & Model 9 & Model 10 & Model 11 & Model 12 & Model 13 \\
\hline \multirow{2}{*}{ Sta } & 0.382209 & $0.002611^{* * *}$ & $0.002433^{* * *}$ & $0.004092^{* * *}$ & $0.003972^{* * *}$ & 0.005842 \\
& $(1.07)$ & $(3.50)$ & $(3.34)$ & $(4.25)$ & $(4.14)$ & $(0.11)$ & $(-0.013730$ \\
$\mathrm{N}$ & 334 & 334 & 334 & 334 & 334 & 334 & 334 \\
R-squared & 0.0316 & 0.1048 & 0.1493 & 0.1098 & 0.1220 & 0.0313 & 0.1404 \\
\hline
\end{tabular}

Note: ${ }^{*},{ }^{* *}$, and ${ }^{* * *}$ represent significance at $10 \%, 5 \%$, and $1 \%$ level, respectively.

TABle 5: The mediation effects test of financing constraints.

\begin{tabular}{|c|c|c|c|c|c|c|c|}
\hline \multirow{2}{*}{ Variables } & \multirow{2}{*}{$\begin{array}{c}\text { Fin } \\
\text { Model } 14\end{array}$} & \multicolumn{2}{|c|}{ Rad } & \multicolumn{2}{|c|}{$\operatorname{Inc}$} & \multicolumn{2}{|c|}{ Ext } \\
\hline & & Model 15 & Model 16 & Model 17 & Model 18 & Model 19 & Model 20 \\
\hline Treat ${ }^{*}$ Post & $\begin{array}{c}-0.004541^{*} \\
(-1.85)\end{array}$ & $\begin{array}{c}0.011056^{* * *} \\
(4.49)\end{array}$ & $\begin{array}{c}0.010246^{* * *} \\
(4.20)\end{array}$ & $\begin{array}{c}0.012348^{* * *} \\
(3.88)\end{array}$ & $\begin{array}{c}0.011223^{* * *} \\
(3.57)\end{array}$ & $\begin{array}{c}0.483211^{* * *} \\
(2.68)\end{array}$ & $\begin{array}{c}0.452091^{* *} \\
(2.50)\end{array}$ \\
\hline Fin & & & $\begin{array}{c}-0.178372^{* * *} \\
(-3.27)\end{array}$ & & $\begin{array}{c}-0.247538^{* * *} \\
(-3.52)\end{array}$ & & $\begin{array}{c}-6.852492^{*} \\
(-1.69)\end{array}$ \\
\hline Age & $\begin{array}{c}-0.000149 \\
(-0.05)\end{array}$ & $\begin{array}{c}0.003807 \\
(1.19)\end{array}$ & $\begin{array}{c}0.003781 \\
(1.19)\end{array}$ & $\begin{array}{c}0.001348 \\
(0.33)\end{array}$ & $\begin{array}{c}0.001311 \\
(0.32)\end{array}$ & $\begin{array}{c}-0.356127 \\
(-1.51)\end{array}$ & $\begin{array}{c}-0.357148 \\
(-1.52)\end{array}$ \\
\hline Size & $\begin{array}{c}0.000891^{* * *} \\
(3.26)\end{array}$ & $\begin{array}{c}0.000187 \\
(0.68)\end{array}$ & $\begin{array}{c}0.000346 \\
(1.26)\end{array}$ & $\begin{array}{c}-0.000172 \\
(-0.49)\end{array}$ & $\begin{array}{c}0.000049 \\
(0.14)\end{array}$ & $\begin{array}{c}0.033943^{*} \\
(1.69)\end{array}$ & $\begin{array}{l}0.040050^{*} \\
(1.97)\end{array}$ \\
\hline Sub & $\begin{array}{c}0.003289^{* * *} \\
(4.76)\end{array}$ & $\begin{array}{c}0.001136 \\
(1.64)\end{array}$ & $\begin{array}{l}0.001723^{* *} \\
\quad(2.44)\end{array}$ & $\begin{array}{c}0.000921 \\
(1.03)\end{array}$ & $\begin{array}{c}0.001735^{*} \\
(1.91)\end{array}$ & $\begin{array}{c}-0.002802 \\
(-0.06)\end{array}$ & $\begin{array}{c}0.019738 \\
(0.38)\end{array}$ \\
\hline Lev & $\begin{array}{c}-0.003606 \\
(-1.13)\end{array}$ & $\begin{array}{c}0.000311 \\
(0.10)\end{array}$ & $\begin{array}{c}-0.000333 \\
(-0.11)\end{array}$ & $\begin{array}{c}0.002428 \\
(0.59)\end{array}$ & $\begin{array}{c}0.001535 \\
(0.38)\end{array}$ & $\begin{array}{c}0.105016 \\
(0.45)\end{array}$ & $\begin{array}{c}0.080308 \\
(0.34)\end{array}$ \\
\hline Sta & $\begin{array}{c}-0.000508 \\
(-0.68)\end{array}$ & $\begin{array}{c}0.002611^{* * *} \\
(3.50)\end{array}$ & $\begin{array}{c}0.002520^{* * *} \\
(3.43)\end{array}$ & $\begin{array}{c}0.004092^{* * *} \\
(4.25)\end{array}$ & $\begin{array}{c}0.003966^{* * *} \\
(4.19)\end{array}$ & $\begin{array}{c}0.005842 \\
(0.11)\end{array}$ & $\begin{array}{c}0.002361 \\
(0.04)\end{array}$ \\
\hline$N$ & 334 & 334 & 334 & 334 & 334 & 334 & 334 \\
\hline$R$-squared & 0.1360 & 0.1048 & 0.1331 & 0.1098 & 0.1424 & 0.0313 & 0.0397 \\
\hline
\end{tabular}

Note: ${ }^{*},{ }^{* *}$, and ${ }^{* * *}$ represent significance at $10 \%, 5 \%$, and $1 \%$ level, respectively.

$[42,43]$, the promotion of subsidies promotes innovation in NEV enterprises by boosting their profits.

4.4. The Mediation Effects Test of Financing Constraints. Second, we use the financing constraint as an intermediate variable to test whether government subsidies can affect the innovation of NEV enterprises by alleviating the financing constraint. From the results in Table 5, the estimated coefficient of the financing constraint in model 14 is negative and significant at the level of $p<10 \%$, indicating that the promotion subsidy reduces the financing constraint of the enterprise's NEVs. Furthermore, models 16, 18, and 20 add the intermediate variable financing constraint to model 14 . The results indicate that internal independent $R \& D$ is positive and significant at the level of $p<1 \%$, while external technology introduction is significantly positive at the level of $p<5 \%$. After controlling for the financing constraint, the regression coefficient of the promotion subsidy on enterprise innovation is still positive and significant. Similarly, the regression coefficient of the financing constraint on enterprise innovation is significantly negative. This implies that the promotion subsidy can promote enterprise innovation by reducing the financing constraint, which plays a partial mediation effect in the relationship between the promotion subsidy and enterprise innovation. Therefore, our hypothesis 3 is verified. This is because the obtained government subsidies not only inject funds into the enterprise's R\&D investment but also send positive signals to the investment institutions outside the enterprise [44]. As an important hidden mechanism for $R \& D$ subsidies to reduce the financing constraints of companies, the signal effect can weaken the information asymmetry between companies and investors and obtain more external financing for enterprises [45]. The innovation of NEV enterprises cannot be separated from a large amount of financial support. Therefore, after NEVs enter the promotion catalogue, promotion subsidies can promote innovation of NEV enterprises by easing financing constraints.

\section{Conclusions and Policy Recommendations}

Our study empirically examines the impact of government promotion subsidy policy on the innovation of NEV enterprises using a multistage DID model with $44 \mathrm{~A}$-shares listed NEV enterprises from 2008 to 2017. The results show that, before entering the NEV promotion catalogue, the government's promotion subsidy policy did not promote innovation of NEV enterprises; after entering the NEV 
promotion catalogue, the government's promotion subsidy policy stimulated innovation of NEV enterprises and significantly promoted radical innovation, incremental innovation, and external technology introduction. In the mediation mechanism examination, our study reveals that entering the promotion catalogue could provide material support for the innovation of NEV enterprises by increasing their profits and easing their financing constraints.

According to the above research findings, our study proposes the policy recommendations as follows:

Firstly, it is necessary to strengthen the breakthrough in core technologies of NEVs. On the basis of cultivating consumption and production capacity, the Chinese government's subsidies for NEVs should focus on the R\&D of key technologies. At the same time, the Chinese government should raise the technical standards for NEVs to enter the promotion catalogue, so as to stimulate the innovative motivation and enthusiasm of NEV enterprises.

Secondly, market demand for the NEV industry should be nurtured. The government should stimulate the enthusiasm and purchasing power of the consumption of NEVs to promote the sustainable development of the market demand. This will guide more social funds into the NEV field and provide financial support for the innovation of enterprises.

Thirdly, the NEV subsidy regulatory system should be improved. The government should increase the intensity of information disclosure to reduce the possibility of financing constraints due to information asymmetry between the government and companies and improve the level of supervision and inspection to increase the illegal cost of enterprises cheating subsidies. At the same time, the government should establish a reasonable elimination mechanism, such as a subsidy rebate mechanism, to shift the main body of NEV development from the government to the market and force enterprises to improve their innovative drive.

\section{Data Availability}

The patent data were manually searched through the patent database of the China National Intellectual Property Administration. The data of promotion subsidy were obtained from the "Catalogue of Recommended Vehicles for the Promotion and Application of New Energy Vehicles" of the MIIT of the People's Republic of China. The other data were obtained from China Stock Market Accounting Research Database (CSMAR), Wind Economic Database (WIND), and missing data were manually supplemented in the annual reports of the companies in Cninfo.

\section{Conflicts of Interest}

The authors declare that there are no conflicts of interest.

\section{Authors' Contributions}

C. J. conceptualized the study; X. W. was responsible for data curation; X. W. provided software; X. W. was responsible for formal analysis; X. W. prepared the original draft; C. J. reviewed and edited the manuscript.

\section{Acknowledgments}

This work was financially supported by the National Social Science Foundation of China (20BGL046).

\section{References}

[1] T. Grublješič, P. S. Coelho, and J. Jaklič, "The shift to socioorganizational drivers of business intelligence and analytics acceptance," zJournal of Organizational and End User Computing, vol. 31, no. 2, pp. 37-64, 2019.

[2] W. Sierzchula, S. Bakker, K. Maat, and B. van Wee, "The influence of financial incentives and other socio-economic factors on electric vehicle adoption," Energy Policy, vol. 68, pp. 183-194, 2014.

[3] H. Guan, Z. Zhang, A. Zhao, and S. Guan, "Simulating environmental innovation behavior of private enterprise with innovation subsidies," Complexity, vol. 2019, Article ID 4629457, 12 pages, 2019.

[4] H. Peng and Y. Liu, "How government subsidies promote the growth of entrepreneurial companies in clean energy industry: an empirical study in China," Journal of Cleaner Production, vol. 188, pp. 508-520, 2018.

[5] F. Yu, L. Wang, and X. Li, "The effects of government subsidies on new energy vehicle enterprises: the moderating role of intelligent transformation," Energy Policy, vol. 141, Article ID 111463, 2020.

[6] H. Zoo, H. J. de Vries, and H. Lee, "Interplay of innovation and standardization: exploring the relevance in developing countries," Technological Forecasting and Social Change, vol. 118, pp. 334-348, 2017.

[7] D. Crane, "Technological innovation in developing countries: a review of the literature," Research Policy, vol. 6, no. 4, pp. 374-395, 1977.

[8] S. Kano, "Technical innovations, standardization and regional comparison-a case study in mobile communications," Telecommunications Policy, vol. 24, no. 4, pp. 305-321, 2000.

[9] L. Z. Zhang, M. Mouritsen, and J. R. Miller, "Role of perceived value in acceptance of "bring your own device" policy," Journal of Organizational and End User Computing, vol. 31, no. 2, pp. 65-82, 2019.

[10] K. Bi, X. Wang, and J. Ge, "380,000+ anesthesia canisters recalled," Biomedical Safety \& Standards, vol. 37, no. 21, pp. 164-165, 2007.

[11] Y. S. Tey, M. Brindal, M. Djama, A. H. I. A. Hadi, and S. Darham, "A review of the financial costs and benefits of the roundtable on sustainable palm oil certification: implications for future research," Sustainable Production and Consumption, vol. 26, pp. 824-837, 2021.

[12] M. Zhang, Y. Wang, and Q. Zhao, "Does participating in the standards-setting process promote innovation? Evidence from China," China Economic Review, vol. 63, Article ID 101532, 2020.

[13] J. Schmookler, "Economic sources of inventive activity," The Journal of Economic History, vol. 22, no. 1, pp. 1-20, 1962.

[14] A. M. Al-Momani, M. A. Mahmoud, and M. S. Ahmad, "Factors that influence the acceptance of internet of things services by customers of telecommunication companies in Jordan," Journal of Organizational and End User Computing, vol. 30, no. 4, pp. 51-63, 2018. 
[15] X. Zhang, K. Wang, Y. Hao, J.-L. Fan, and Y.-M. Wei, "The impact of government policy on preference for NEVs: the evidence from China," Energy Policy, vol. 61, pp. 382-393, 2013.

[16] X. Gao and V. Rai, "Local demand-pull policy and energy innovation: evidence from the solar photovoltaic market in China," Energy Policy, vol. 128, pp. 364-376, 2019.

[17] S.-C. Ma, Y. Fan, and L. Feng, "An evaluation of government incentives for new energy vehicles in China focusing on vehicle purchasing restrictions," Energy Policy, vol. 110, pp. 609-618, 2017.

[18] W. Zeng, L. Li, and Y. Huang, "Industrial collaborative agglomeration, marketization, and green innovation: evidence from China's provincial panel data," Journal of Cleaner Production, vol. 279, Article ID 123598, 2021.

[19] J. Lerner, "The government as venture capitalist: the long-run impact of the SBIR program," The Journal of Business, vol. 72, no. 3, pp. 285-318, 1999.

[20] M. Meuleman and W. De Maeseneire, "Do R\&D subsidies affect SMEs' access to external financing?" Research Policy, vol. 41, no. 3, pp. 580-591, 2012.

[21] A. Wu, "The signal effect of Government R\&D Subsidies in China: does ownership matter?” Technological Forecasting and Social Change, vol. 117, pp. 339-345, 2017.

[22] D. Czarnitzki and H. Hottenrott, "R\&D investment and financing constraints of small and medium-sized firms," Small Business Economics, vol. 36, no. 1, pp. 65-83, 2011.

[23] B. Hall and J. Lerner, "The financing of R\&D and innovation," Handbook of the Economics of Innovation, vol. 1, pp. 609-639, 2010.

[24] N. Xu, N. Jiang, and J. Zhang, "Index," Jewish Peoplehood, vol. V40, pp. 163-172, 2019.

[25] Y. Xue, "Make or buy new technology: the role of CEO compensation contract in a firm's route to innovation," Review of Accounting Studies, vol. 12, no. 4, pp. 659-690, 2007.

[26] C. Jiang, Y. Zhang, M. Bu, and W. Liu, "The effectiveness of government subsidies on manufacturing innovation: evidence from the new energy vehicle industry in China," Sustainability, vol. 10, no. 6, p. 1692, 2018.

[27] C. Jiang, Y. Zhang, Q. Zhao, and C. Wu, "The impact of purchase subsidy on enterprises' R\&D efforts: evidence from China's new energy vehicle industry," Sustainability, vol. 12, no. 3, p. 1105, 2020.

[28] S. Guangjun, Y. Yang, and Z. Ninghua, "Financing constraints of private firms and the structural problem in China's labor market," Management World, vol. 36, pp. 41-211, 2020.

[29] J. Plank and C. Doblinger, "The firm-level innovation impact of public R\&D funding: evidence from the German renewable energy sector," Energy Policy, vol. 113, pp. 430-438, 2018.

[30] Y. Zhao, X. Zhang, W. Jiang, and T. Feng, "Does second-order social capital matter to green innovation? The moderating role of governance ambidexterity," Sustainable Production and Consumption, vol. 25, pp. 271-284, 2021.

[31] J. Cailou, Z. Fuyu, and W. Chong, "Environmental information disclosure, political connections and innovation in high-polluting enterprises," Science of The Total Environment, vol. 764, Article ID 144248, 2021.

[32] X. Lv, Y. Qi, and W. Dong, "Dynamics of environmental policy and firm innovation: asymmetric effects in Canada's oil and gas industries," Science of The Total Environment, vol. 712, Article ID 136371, 2020.

[33] X. Cai, B. Zhu, H. Zhang, L. Li, and M. Xie, "Can direct environmental regulation promote green technology innovation in heavily polluting industries? Evidence from Chinese listed companies," Science of The Total Environment, vol. 746, Article ID 140810, 2020.

[34] Y. Wu, F. Gu, Y. Ji, J. Guo, and Y. Fan, "Technological capability, eco-innovation performance, and cooperative $R \& D$ strategy in new energy vehicle industry: evidence from listed companies in China," Journal of Cleaner Production, vol. 261, Article ID 121157, 2020.

[35] Y. Tu and $\mathrm{W}$. Wu, "How does green innovation improve enterprises' competitive advantage? The role of organizational learning," Sustainable Production and Consumption, vol. 26, pp. 504-516, 2021.

[36] J. R. Edwards and L. S. Lambert, "Methods for integrating moderation and mediation: a general analytical framework using moderated path analysis," Psychological Methods, vol. 12, no. 1, pp. 1-22, 2007.

[37] C. B. Mohnen, "Are firms that receive R\&D subsidies more innovative?" Canadian Journal of Economics, vol. 42, pp. 206-225, 2009.

[38] R. Bronzini and P. Piselli, "The impact of R\&D subsidies on firm innovation," Research Policy, vol. 45, no. 2, pp. 442-457, 2016.

[39] K.-N. Kang and H. Park, "Influence of government R\&D support and inter-firm collaborations on innovation in Korean biotechnology SMEs," Technovation, vol. 32, no. 1, pp. 68-78, 2012.

[40] N. Duch-Brown, D. Montolio, and M. Mediavilla, "Evaluating the impact of public subsidies on a firm's performance: a quasi-experimental approach," SSRN Electronic Journal, pp. 143-165, 2009.

[41] A. Cerqua and G. Pellegrini, "Do subsidies to private capital boost firms' growth? A multiple regression discontinuity design approach," Journal of Public Economics, vol. 109, pp. 114-126, 2014.

[42] H. D. Kurz, "Innovations and profits," Journal of Economic Behavior \& Organization, vol. 67, no. 1, pp. 263-278, 2008.

[43] B. Lin and R. Luan, "Are government subsidies effective in improving innovation efficiency? Based on the research of China's wind power industry," Science of The Total Environment, vol. 710, Article ID 136339, 2020.

[44] T. Takalo and T. Tanayama, "Adverse selection and financing of innovation: is there a need for R\&D subsidies?" The Journal of Technology Transfer, vol. 35, no. 1, pp. 16-41, 2010.

[45] J. Chen, C. S. Heng, B. C. Y. Tan, and Z. Lin, "The distinct signaling effects of $\mathrm{R} \& \mathrm{D}$ subsidy and non-R\&D subsidy on IPO performance of IT entrepreneurial firms in China," Research Policy, vol. 47, no. 1, pp. 108-120, 2018. 